\title{
HydROGEN AND OXYGEN StABLE IsOTOPE RATIOS OF DOlOMITE-RelATED NePHRITE: ReLEVANCE FOR ITS GeOGRAPHIC ORIGIN AND GeOlOGiCAl SigNIFICANCE
}

Kong Gao, Ting Fang, Taijin Lu, Yan Lan, Yong Zhang, Yuanyuan Wang, and Yayun Chang

Hydrogen and oxygen stable isotope ratios of dolomite-related nephrites around the world were studied using data from the literature $(n=120)$. These isotope ratios are highly effective for discriminating dolomite-related nephrites from the four most important origins worldwide. Nephrite from Vitim in Russia has the lowest isotope ratio values reflected in $\delta^{2} \mathrm{H}$ and $\delta^{18} \mathrm{O}$ values, followed by Chuncheon in South Korea and then Xinjiang Uyghur Autonomous Region in China. Nephrite from Sanchakou in the Qinghai Province of China has the highest values. Other occurrences are characterized by high $\delta^{18} \mathrm{O}$ values similar to or higher than those of samples from Sanchakou. The differences are derived mainly from the ore-forming fluids. Vitim and Chuncheon isotope ratio values were mainly affected by meteoric water (rainwater, lake water, seawater, river water, glacial water, and shallow groundwater). Xinjiang nephrite-forming fluids were mixtures of magmatic hydrothermal fluids (able to be modified by metamorphism) and meteoric water. The hydrothermal fluids forming the Qinghai, Luodian, Dahua, and Xiuyan nephrites underwent some metamorphic alteration or regional metamorphism.

$\mathrm{N}$ ephrite is a near-monomineralic rock composed of tremolite-actinolite, $\mathrm{Ca}_{2}(\mathrm{Mg}, \mathrm{Fe})_{5} \mathrm{Si}_{8} \mathrm{O}_{22}(\mathrm{OH})_{2}$. It occurs worldwide (figure 1) and is classified as dolomite-related or serpentine-related according to the different parent rocks and ore-hosting rocks, and both types form by metasomatism (Yui et al., 1988; Tang et al., 1994; Yang and Abduriyim, 1994; Harlow and Sorensen, 2005; Burtseva et al., 2015). The large and well-known dolomite-related nephrite deposits are distributed in the Xinjiang Uyghur Autonomous Region (hereafter abbreviated as Xinjiang) of China, Qinghai Province of China, Siberia in Russia, and Chuncheon in South Korea (figure 1). Data from smaller-scale deposits such as Val Malenco in Italy and Złoty Stok in Poland are also used in this study (figure 1). The rest of the data were collected from nephrites produced at multiple small-scale

See end of article for About the Authors and Acknowledgments.

Gems \& Gemology, Vol. 56, No. 2, pp. 266-280,

http://dx.doi.org/10.5741/GEMS.56.2.266

(C) 2020 Gemological Institute of America sources in China: Xiuyan, Tanghe, Dahua, and Luodian (figure 2).

With nephrite jade, a premium is placed on geographic origin since the gem's cultural significance differs by location. It is possible to have an opinion

\section{In Brief}

- Geographic origin can have a significant impact on the value of nephrite.

- Hydrogen and oxygen stable isotope ratios, particularly the latter, provide a robust tool for origin determination.

- Dolomite-related nephrites from Vitim, Chuncheon, Xinjiang, and Qinghai differ from one another by distinct hydrogen and oxygen stable isotope ratios.

- Differences in hydrogen and oxygen stable isotope ratios for nephrite are related to ore-forming fluids.

on the origin of a small amount of nephrite by simple visual examination, since some varieties with unique 


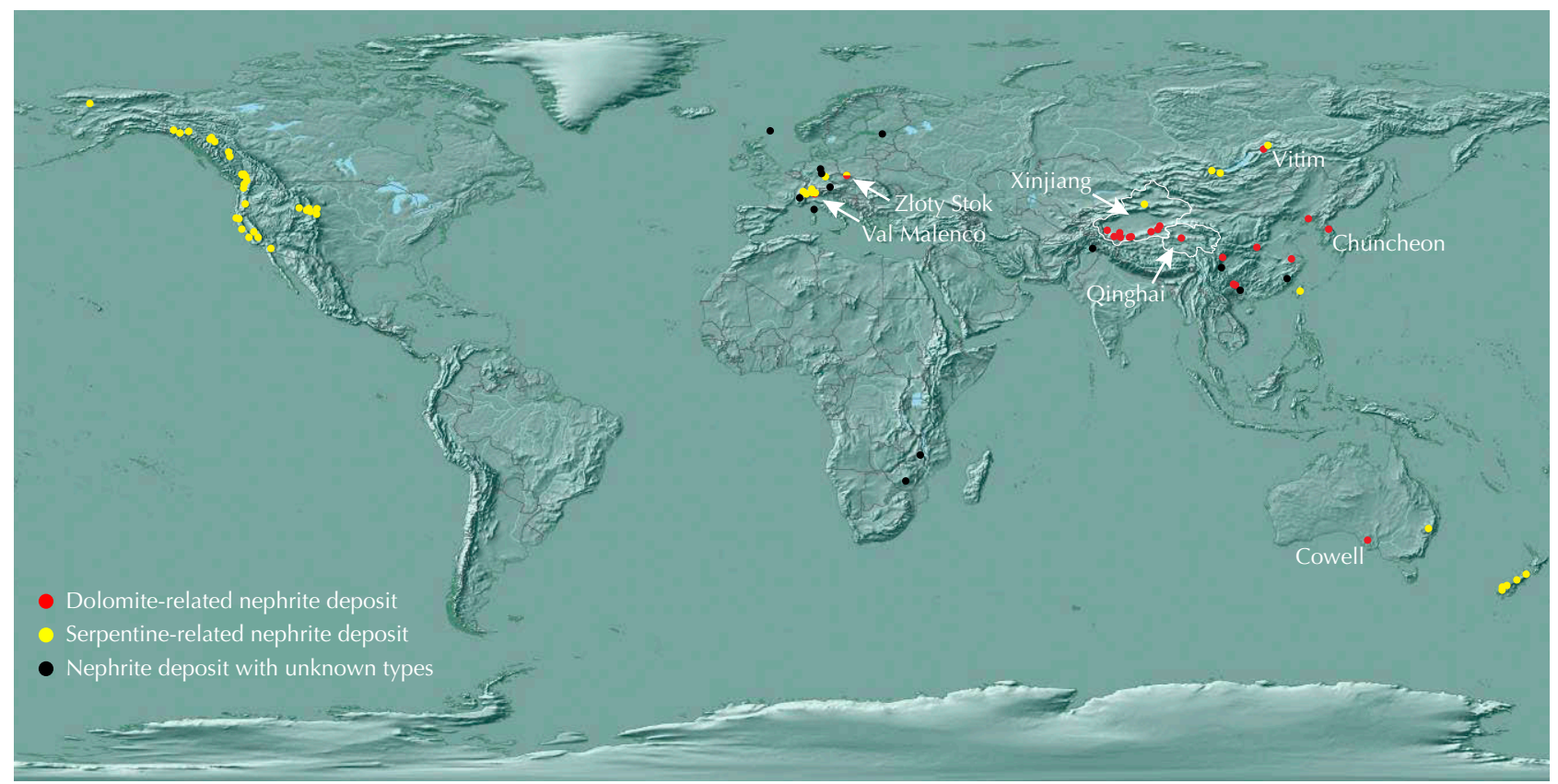

Figure 1. Distribution map of reported nephrite deposits worldwide. The four most important dolomite-related nephrite sources are Vitim in Russia, Chuncheon in South Korea, and Xinjiang and Qinghai in China. From @naturalearthdata.com.

gemological characteristics such as color, luster, and transparency have mainly occurred in specific deposits. In Xinjiang, for example, high-quality white primary nephrite occurs in Qiemo County. ${ }^{1}$ There it is commonly associated with brown nephrite (figure $3 \mathrm{~A}$, rough with white core and very thick brown rind). The brown is a color seldom found in nephrite from other deposits in Xinjiang. The highest-quality white primary nephrite (figure $3 \mathrm{~B}$, white plate) mostly comes from the Hetian region and Qiemo County. Placer nephrite (figures 3C and 3D, pendants with figures carved out of brownish red skin) occurs in the Yulongkashi River and Kalakashi River basins. A considerable quantity of primary nephrite from Ruoqiang County features a yellow color component (figure 3E, greenish yellow fish) that is absent from other samples. Black nephrite (figure 3F, bangle bracelet) colored by graphite, on the other hand, mainly occurs in the Hetian region and has not been found in Qiemo County or Ruoqiang County. However, the origin determination of a tremendous amount of dolomite-related nephrite cannot be solved by this simple observation. Previous researchers used trace elements combined with appearance to identify geographic origin and obtained some

${ }^{1}$ This paper uses Chinese pinyin to express all Chinese location names involved, and the corresponding commonly used English names are listed in table 1. informative results (Zhong et al., 2013; Luo et al., 2015). Unfortunately, rigorous and scientific determination of geographic origin is still not available.

Hydrogen and oxygen isotope ratio values (see box A), which might vary for the same gemstone from different regions due to diverse ore-forming environments and models, can be used for geographic origin determi-

TABLE 1. Location names expressed in Chinese pinyin and their English equivalents.

\begin{tabular}{ll}
\hline \multicolumn{1}{c}{ Chinese pinyin } & \multicolumn{1}{c}{ English } \\
\hline A'erjinshan & Altyn Tagh \\
Alamasi & Alamas \\
Bayinguoleng region & Bayingholin region \\
Hetian & Hoten/Hotan \\
Kalakashi, Hetian & Qaraqash, Hoten \\
Kashi region & Kashkar region \\
Keliya River & Keriye/Keriya River \\
Qiemo County, Bayinguoleng & Cherchen County, Bayingholin \\
Ruoqiang County, Bayinguoleng & Chaqiliq County, Bayingholin \\
Takelamagan Desert & Taklimakan Desert \\
Tashiku'ergan County & Taxkorgan/Tashkurghan County \\
Yecheng County, Kashi & Qaghiliq County, Kashkar \\
Yulongkashi, Hetian & Yurungqash, Hoten \\
Yutian County & Keriye County, Hoten
\end{tabular}



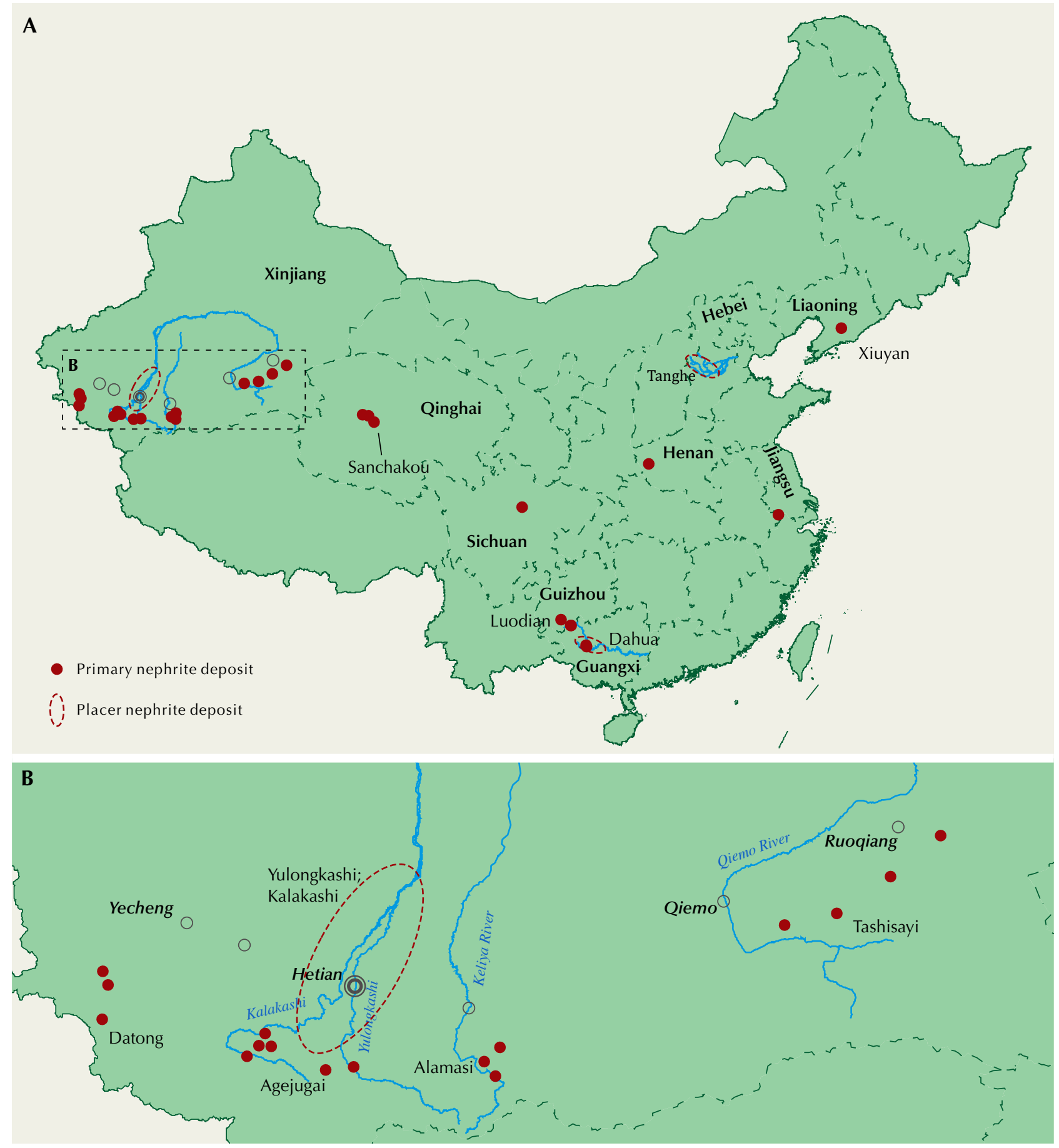

Figure 2. The distribution of main dolomite-related nephrite deposits of China. Primary and placer nephrite occur at Xiuyan, but the latter is not plotted in the map.

nation (Giuliani et al., 1998, 2000, 2005, 2007). A mass spectrometer is needed to determine the isotope ratio values (see box B). The spot produced by secondary ion mass spectrometry (SIMS), laser ablation-inductively coupled plasma-mass spectrometry (LA-ICP-MS), and laser ablation inductively coupled plasma time-of- flight mass spectrometry (LA-ICP-TOF-MS) for stable isotope analysis of gemstones can be restricted to craters of $10-100 \mu \mathrm{m}$ in diameter and a few angstroms to microns deep (Giuliani et al., 2000, 2005; Abduriyim and Kitawaki, 2006; Wang et al., 2016, 2018). The craters produced are very small, to the point of not 

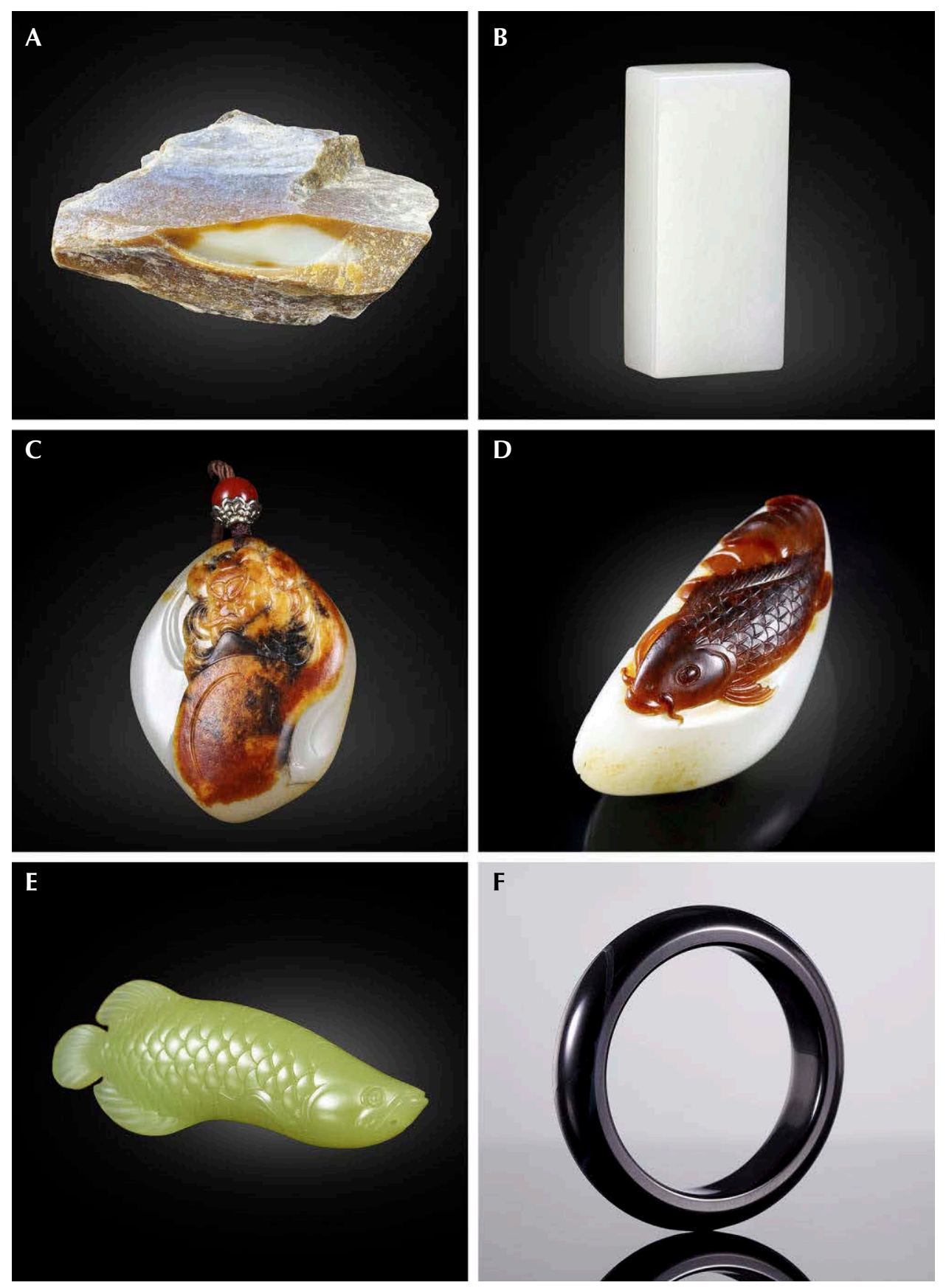

Figure 3. Nephrites from different localities of Xinjiang showing distinct appearances. A: The rough is a typical piece of white-brown nephrite from Qiemo County. B: The white plate is primary nephrite of the highest quality, which occurs in both the Hetian region and Qiemo County. C and D: Two pendants carved from placer nephrite collected in the Hetian region feature brownish red skin sculpted into different figures. E: The greenish yellow fish features a yellow color component of primary nephrite from Ruoqiang. F: Black nephrite like that of the bangle bracelet mainly occurs in the Hetian region. Photos by Dong He; courtesy of Elegant China.

being noticeable without magnification. This permits the method to be applied to gemstones and historical antiques (Giuliani et al., 2000, 2005).

Geographic origin discrimination of nephrite by isotopes is seldom reported, even though many hydrogen and oxygen isotope ratio studies on this material have been carried out (table 2). By summarizing and analyzing all available hydrogen and oxygen isotopic data of dolomite-related nephrites worldwide from published references, this study discusses the geographic origin discrimination based on the rela- tionship between the characteristics of nephrite and its formation environment.

\section{WHY DO ISOTOPE RATIOS MATTER TO GEMOLOGISTS?}

The application of isotopes has gradually attracted the attention of gemologists (Wang et al., 2016). In addition to hydrogen and oxygen isotope ratios, which can help determine the geographical origins of corundum and emerald (Giuliani et al., 1998, 2000, 2005, 2007; Wang 


\section{Box A: Introduction to Oxygen and Hydrogen Stable Isotope Ratios}

Atoms with an equivalent atomic number (i.e., atoms of the same element) can differ from one another in their number of neutrons. For example, ${ }^{18} \mathrm{O}$ has 8 protons and 10 neutrons, and ${ }^{16} \mathrm{O}$ has 8 protons and 8 neutrons; ${ }^{2} \mathrm{H}$, also known as deuterium (D), has 1 proton and 1 neutron, while ${ }^{1} \mathrm{H}$ has 1 proton and no neutrons. Such atoms with the same number of protons but different numbers of neutrons are defined as isotopes.

The mass difference inherent from divergent neutrons causes isotopic fractionation, which occurs as the isotopes of an element are distributed between two substances or phases in differing ratios in a given system. This process can be affected by temperature, equilibrium or kinetic processes, and other physiochemical processes. The isotope fractionation will reach and maintain equilibrium unless conditions change. Therefore, isotope abundance can be used as a tracer to reveal certain geochemical processes in geological bodies.

Isotope ratio, defined as the measured relative abundance of a heavy isotope to its lighter counterpart (e.g., ${ }^{18} \mathrm{O} /{ }^{16} \mathrm{O}$ and $\left.{ }^{2} \mathrm{H} /{ }^{1} \mathrm{H}\right)$, is typically used rather than the isotope abundance itself. The isotopic fractionation factor $(\alpha)$ is introduced to represent the extent of fractionation of isotopes between two phases. It is defined as the ratio of isotope ratios in one phase to the other coexisting phase. For example, in a system consisting of phase A and phase $\mathrm{B}$, the oxygen isotope fractionation factor can be defined as

$$
\alpha_{\mathrm{A}-\mathrm{B}}=\frac{\left({ }^{18} \mathrm{O} /{ }^{16} \mathrm{O}\right)_{\mathrm{A}}}{\left({ }^{18} \mathrm{O} /{ }^{16} \mathrm{O}\right)_{\mathrm{B}}}
$$

The isotopic fractionation factor is always a function of temperature, which can be obtained by theoretical calculation or experiment (Graham et al., 1984; Zheng, 1993, 1995).

Both oxygen and hydrogen isotope ratios are also reported in so-called delta notation given in terms of per mil (\%o). In other words, the delta value

$$
\delta^{18} \mathrm{O}=\frac{\left({ }^{18} \mathrm{O} /{ }^{16} \mathrm{O}\right)_{\text {sample }}-\left({ }^{18} \mathrm{O} /{ }^{16} \mathrm{O}\right)_{\text {standard }}}{\left({ }^{18} \mathrm{O} /{ }^{16} \mathrm{O}\right)_{\text {standard }}} \times 1000 \%
$$

and

$$
\delta^{2} \mathrm{H}=\frac{\left({ }^{2} \mathrm{H} /{ }^{1} \mathrm{H}\right)_{\text {sample }}-\left({ }^{2} \mathrm{H} /{ }^{1} \mathrm{H}\right)_{\text {standard }}}{\left({ }^{2} \mathrm{H} /{ }^{1} \mathrm{H}\right)_{\text {standard }}} \times 1000 \%
$$

in which ${ }^{18} \mathrm{O} /{ }^{16} \mathrm{O}$ and ${ }^{2} \mathrm{H} /{ }^{1} \mathrm{H}$ are the isotope ratios defined above. Values of delta $>0$ indicate that relative to the standard samples, the tested sample has a higher heavy isotope abundance, and a negative delta value indicates a higher light isotope abundance.

International general isotope standards are issued by the International Atomic Energy Agency (IAEA) and the U.S. National Institute of Standards and Technology (NIST). The delta values of hydrogen and oxygen isotopes are calculated using the value for Standard Mean Ocean Water (SMOW), which has ${ }^{2} \mathrm{H} /{ }^{1} \mathrm{H}$ of $(155.76 \pm$ $0.10) \times 10^{-6},{ }^{18} \mathrm{O} /{ }^{16} \mathrm{O}$ of $(2005.20 \pm 0.43) \times 10^{-6}$, and ${ }^{17} \mathrm{O} /{ }^{16} \mathrm{O}$ of $(373 \pm 15) \times 10^{-6}$. Other hydrogen isotope standard samples include SLAP, GISP, NBS-22, and NBS-30. et al., 2019), carbon isotopes are considered useful in identifying natural and synthetic diamonds (Wang et al., 2014), and radioactive isotopes have also been used to determine the ages of gemstones (Link, 2015).

Traditional methods using the parameters of inclusions, optical characteristics, and trace elements are often not enough to solve the problems of geographic origin determination of nephrite. Isotopic analysis has provided geochemical and chronological information for all sorts of geological samples: Stable isotopes can be used to study gemstone origin /source materials, formation process, and geographical localities), whereas radioactive isotopes can be utilized to determine the formation ages. The stable isotope study of dolomite-related nephrite in our works, together with previous studies on corundum and emerald (Giuliani et al., 1998, 2000, 2005, 2007; Wang et al., 2019), show that the geographic origin characteristics of isotopes in gemstones can be explained from their formation environment and formation process.
Thus, relative isotopic abundances are reliable parameters for determining geographic origin and offer a sound complement to traditional methods.

\section{DATA AND CALCULATION}

In all, 120 sets of hydrogen and oxygen isotope data (some lacking hydrogen data) for dolomite-related nephrites were collected from all known related published studies, from a variety of researchers (table 2 and figure 4), to illustrate geographic origin discrimination with stable isotopic ratios.

Hydrogen and oxygen isotope delta values of nephrite can be used to calculate the corresponding values of its formation fluids. Hydrogen isotope fractionation of tremolite relative to water is not affected by temperature in the approximate range of $350^{\circ}$ to $650^{\circ} \mathrm{C}$ (Graham et al., 1984), and thus

$$
10^{3} \ln \alpha_{\mathrm{Tr}-\mathrm{H}_{2} \mathrm{O}}=-21.7 \pm 2
$$


while oxygen isotope fractionation (Zheng, 1993, 1995) can be expressed as

$$
10^{3} \ln \alpha_{\mathrm{Tr}-\mathrm{H}_{2} \mathrm{O}}=\left(3.95 \times 10^{6} / \mathrm{T}^{2}\right)-\left(8.28 \times 10^{3} / \mathrm{T}\right)+2.38
$$

In both equations, $\alpha_{\mathrm{Tr}-\mathrm{H}_{2} \mathrm{O}}$ is the isotopic fractionation factor (see box A) between the nephrite and its formation fluid, and $\mathrm{T}$ is the absolute temperature $(\mathrm{K})$ of the nephrite-forming system. The nephrite formation temperature is confined to approximately $223^{\circ}-425^{\circ} \mathrm{C}$, especially near $350^{\circ} \mathrm{C}$ (Tang et al., 1994; Yui and Kwon, 2002; Chen et al., 2014; Liu et al., 2016), by methods using the homogenization temperatures of tremolite fluid inclusions (Liu et al., 2011a; Chen et al., 2014), the combination of the pyrite decrepitation temperature and calcite homogenization temperature (Wang et al., 2007; Xu and Wang, 2016), the mineral assemblage (Yang, 2013), and isotopes (Yui et al., 1988). Thus, the value of $350^{\circ} \mathrm{C}$ was used to calculate the isotopes of fluids from which nephrite forms.

Both the isotope fractionation factor $\alpha_{\mathrm{Tr}-\mathrm{H}_{2} \mathrm{O}}$ and delta values $\left(\delta^{18} \mathrm{O}, \delta^{2} \mathrm{H}\right)$ are defined after isotope ratios $\left({ }^{18} \mathrm{O} /{ }^{16} \mathrm{O},{ }^{2} \mathrm{H} /{ }^{1} \mathrm{H}\right)$ of nephrite and its formation fluids (see box A). Thus, the delta values of the nephriteforming fluids $\left(\delta^{18} \mathrm{O}_{\mathrm{Tr}-\mathrm{H}_{2} \mathrm{O}}, \delta^{2} \mathrm{H}_{\mathrm{Tr}-\mathrm{H}_{2} \mathrm{O}}\right.$ table 2$)$ can be cal- culated from the delta values of corresponding nephrite, which is acquired by isotope determination (see box B).

\section{GEOGRAPHIC ORIGIN CHARACTERISTICS}

Vitim in Russia, Chuncheon in South Korea, and Xinjiang and Qinghai in China are the four most important dolomite-related nephrite source areas. The relative abundances of the hydrogen and oxygen isotopes of nephrites from these regions differ significantly (figure 4). In particular, oxygen isotope $\delta^{18} \mathrm{O}$ values (see figure 4 and table 2 ) range from $-20.0 \%$ to $-14.6 \%$ o, $-9.9 \%$ o to $-8.2 \%$ o, $0.5 \%$ o to $7.9 \%$, and $11.4 \%$ o to $12.6 \%$, respectively, without any overlap. Cowell in Australia is considered another large dolomite-related nephrite deposit but is seldom studied. The only $\delta^{2} \mathrm{H}-\delta^{18} \mathrm{O}$ data (see figure 4 and table 2 ) fall within the range of Xinjiang placer nephrite; nevertheless, the $\delta^{2} \mathrm{H}$ values are significantly higher than those of Xinjiang primary nephrite.

The nephrites from Xinjiang, distributed in a belt longer than $1300 \mathrm{~km}$, show convergent hydrogen and oxygen isotopic characteristics. The isotope delta values of their primary dolomite-related nephrites are covered by placer ones (figure 4).

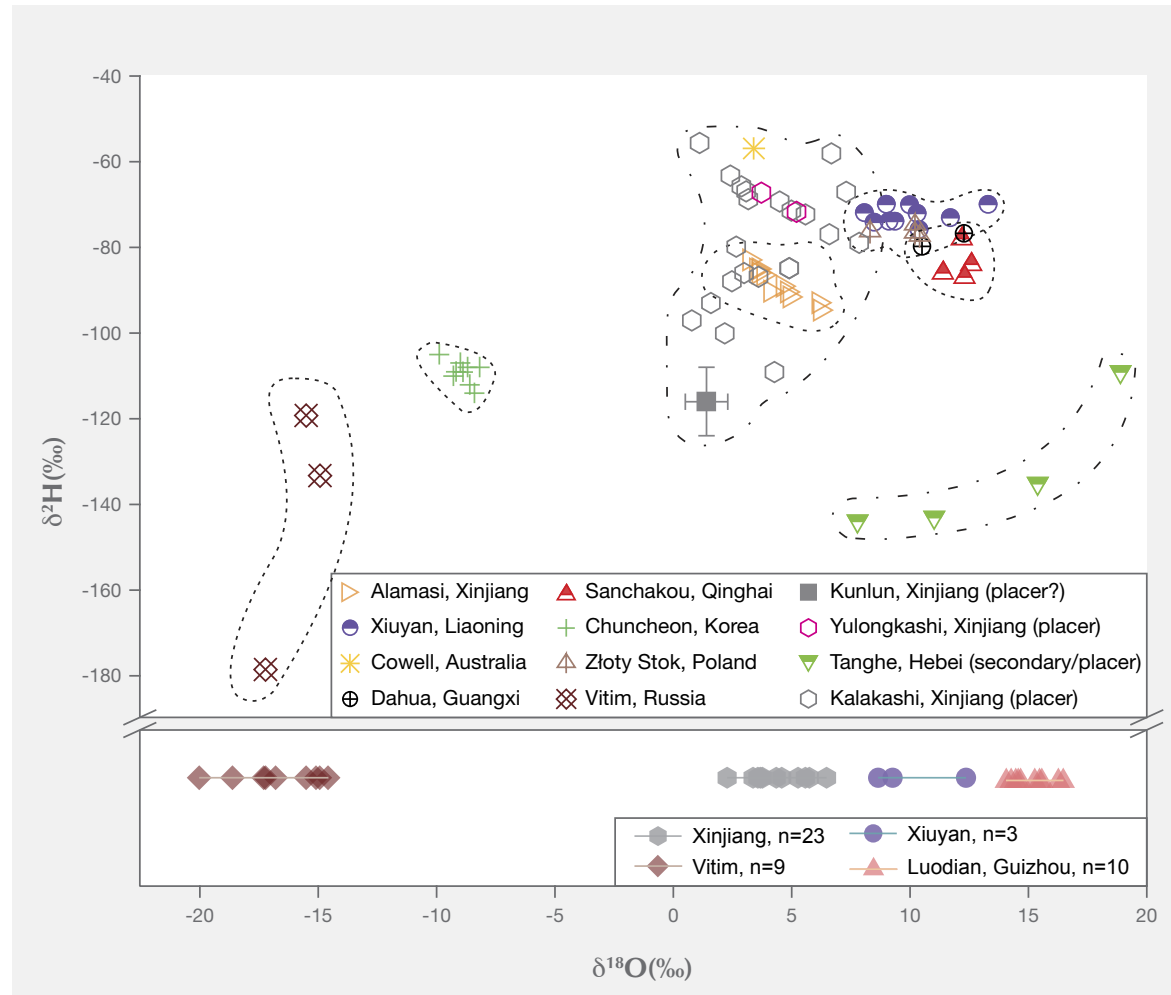

Figure 4. Hydrogen and oxygen isotopic compositions (top), and oxygen isotopic composition only (bottom), of dolomite-related nephrites around the world. 


\section{Box B: ANalytical Methods for Determining Oxygen and HYDROGEN ISOTOPE CONCENTRATIONS}

Isotope concentrations are commonly measured with a mass spectrometer operating on the principle that the degree of deflection of charged particles in a magnetic field is inversely proportional to the mass-to-charge ratio $(\mathrm{m} / \mathrm{z})$ (figure B-1). Generally, mass spectrometers can be divided into four parts: the sampling system, the ion source, the mass analyzer, and the detector.

Stable isotope analysis has advanced from macroanalysis to microanalysis and now includes methods of static mass spectrometry, laser ablation (multi-collector)-inductively coupled plasma-mass spectrometry (LA(MC)-ICP-MS), and secondary ion mass spectrometry (SIMS). High accuracy and low sample loss make these technologies suitable for isotopic analysis of gemstones.

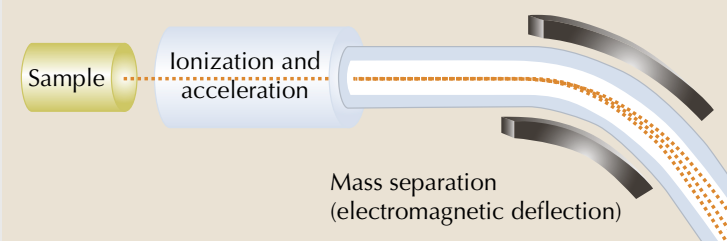

Figure B-1. The basic schematic of mass spectrometry. Modified from chem.libretexts.org.
Samples from some relatively small deposits such as Xiuyan in Liaoning Province, Złoty Stok in Poland, and Dahua in Guangxi Province (figure 4) show slightly higher $\delta^{2} \mathrm{H}$ values than those of Qinghai nephrite and Xinjiang primary nephrite. Their ranges of $\delta^{18} \mathrm{O}$ values cover that of Sanchakou samples but do not overlap with Xinjiang primary nephrite. Fortunately, nephrites from these three regions typically have their own distinct appearances. Luodian nephrite from Guizhou has notably higher $\delta^{18} \mathrm{O}$ values than the others (no $\delta^{2} \mathrm{H}$ value data have been collected). In recent years, secondary nephrite has been found in the Tanghe River in Hebei Province. It is speculated to be a dolomite-related nephrite according to the regional geology, field observation, and petrographic analysis (Chen et al., 2014). Its hydrogen and oxygen isotope ratios are completely isolated from others in the plot of $\delta^{2} \mathrm{H}-\delta^{18} \mathrm{O}$ (figure 4) by low $\delta^{2} \mathrm{H}$ and high $\delta^{18} \mathrm{O}$ values.

\section{NEPHRITE-FORMING FLUIDS FROM MAGMATIC WATER AND METEORIC WATER}

Fluids containing gases, liquids, and silicate compositions always occur as the most active parts of geological processes. They are composed mainly of $\mathrm{H}_{2} \mathrm{O}$, $\mathrm{CO}_{2}, \mathrm{NaCl}$, metal components, silicate compositions, and organic matter. The fluids that correspond to nephrite formation are hydrothermal fluids, which refer to gas-liquid two-phase systems having their own temperatures and pressures. Hydrothermal flu- ids are released from magma (magmatic fluids) or metamorphism (metamorphic fluids) due to changes in temperature and pressure. They also can be meteoric waters (including rainwater, lake water, seawater, river water, glacial water, and shallow groundwater) heated by geological processes.

The original characteristics of the hydrogen and oxygen isotopes of nephrite mainly result from the ore-forming fluids. The calculated $\delta^{2} \mathrm{H}_{\mathrm{Tr}-\mathrm{H}_{2} \mathrm{O}}$ and $\delta^{18} \mathrm{O}_{\mathrm{H}_{2} \mathrm{O}}$ values of hydrothermal fluids forming the Vitim and Chuncheon nephrites plot near the Craig line $^{2}$ (figure 5), indicating that their predominant oreforming fluids were meteoric waters in an environment with a high fluid/rock ratio (Yui and Kwon, 2002; Burtseva et al., 2015).

For the Xinjiang nephrite, magmatic fluid, meteoric water, and metamorphic water are all possible candidates for the ore-forming fluids (figure 5), and a low fluid/rock ratio is indicated (Yui and Kwon, 2002; Liu et al., 2011a, 2011b, 2016). The $\delta^{18} \mathrm{O}_{\mathrm{H}_{2} \mathrm{O}}$ values of the nephrite-forming fluids for Alamasi nephrite, which occurs in granite-dolomite contact zones (Liu et al., 2010, 2011a), decrease in the con-

\footnotetext{
${ }^{2}$ The Craig line, also referred to as the meteoric water line, represents the relationship between $\delta^{2} \mathrm{H}$ and $\delta^{18} \mathrm{O}$ of meteoric water-i.e., $\delta^{2} \mathrm{H}=$ $8 \delta^{18} \mathrm{O}+10$ (Craig, 1961). The kaolinite line (Zheng and Chen, 2000) shown in figure 5 represents the relationship between $\delta^{2} \mathrm{H}$ and $\delta^{18} \mathrm{O}$ of kaolinite in weathering profile (i.e., $\delta^{2} \mathrm{H}=7.5 \delta^{18} \mathrm{O}-220$ ). Most of the soil samples in nature fall on or near the kaolinite line.
} 
tact zone in the order of granite $\rightarrow$ nephrite $\rightarrow$ wall rock. The $\delta^{18} \mathrm{O}_{\mathrm{H}_{2} \mathrm{O}}$ values of magmatic fluids, seldom influenced by crustal rocks during intrusion, should equal the high values of the Xinjiang nephrite-forming fluids (figure 5). The $\delta^{18} \mathrm{O}_{\text {dol }}$ values of wall rock are far lower than those of common carbonates of sedimentary origin, at only $6.1 \%$ (Wan et al., 2002). Then, the $\delta^{18} \mathrm{O}_{\mathrm{H}_{2} \mathrm{O}}$ value for the water in equilibrium with wall rock is $1.6 \%$ o $\left(1000 \ln \alpha_{\mathrm{dol}_{-} \mathrm{H} O}=3.06 \times\right.$ $10^{6} / \mathrm{T}^{2}-3.24$ after Zheng and Chen (2000), assuming that the temperature for the wall rock during nephrite formation was between $252^{\circ}$ and $295^{\circ} \mathrm{C}$ ). This value is lower than those of the fluids in equilibrium with most of the Xinjiang nephrite (figure 5). In addition, considering the characteristics of the chemical zoning (Liu et al., 2010), the higher $\delta^{18} \mathrm{O}_{\mathrm{H}_{2} \mathrm{O}}$ values for green nephrite fluids than for white ones in the Alamasi deposit (Wan et al., 2002) provide another indicator that oxygen isotopes decrease from granite to wall rock. However, the $\delta^{18} \mathrm{O}_{\mathrm{H}_{2} \mathrm{O}}$ value should have increased gradually if water unilaterally diffused from the granite to the wall rock, since water in equilibrium with nephrite is enriched or slightly depleted in ${ }^{18} \mathrm{O}$ /depending on the temperature, calculated according to Equation 2 with $\mathrm{T}$ around $350^{\circ} \mathrm{C}$. Considering that the $\delta^{2} \mathrm{H}$ value of the Alamasi nephrite is negatively related to the $\delta^{18} \mathrm{O}$ value (figure 4), the conflict can be explained by dualistic fluid sources. One is post-magmatic hydrothermal fluids provided by the granite forming the nephrite, while the other must be the meteoric water from the dolomite marble.

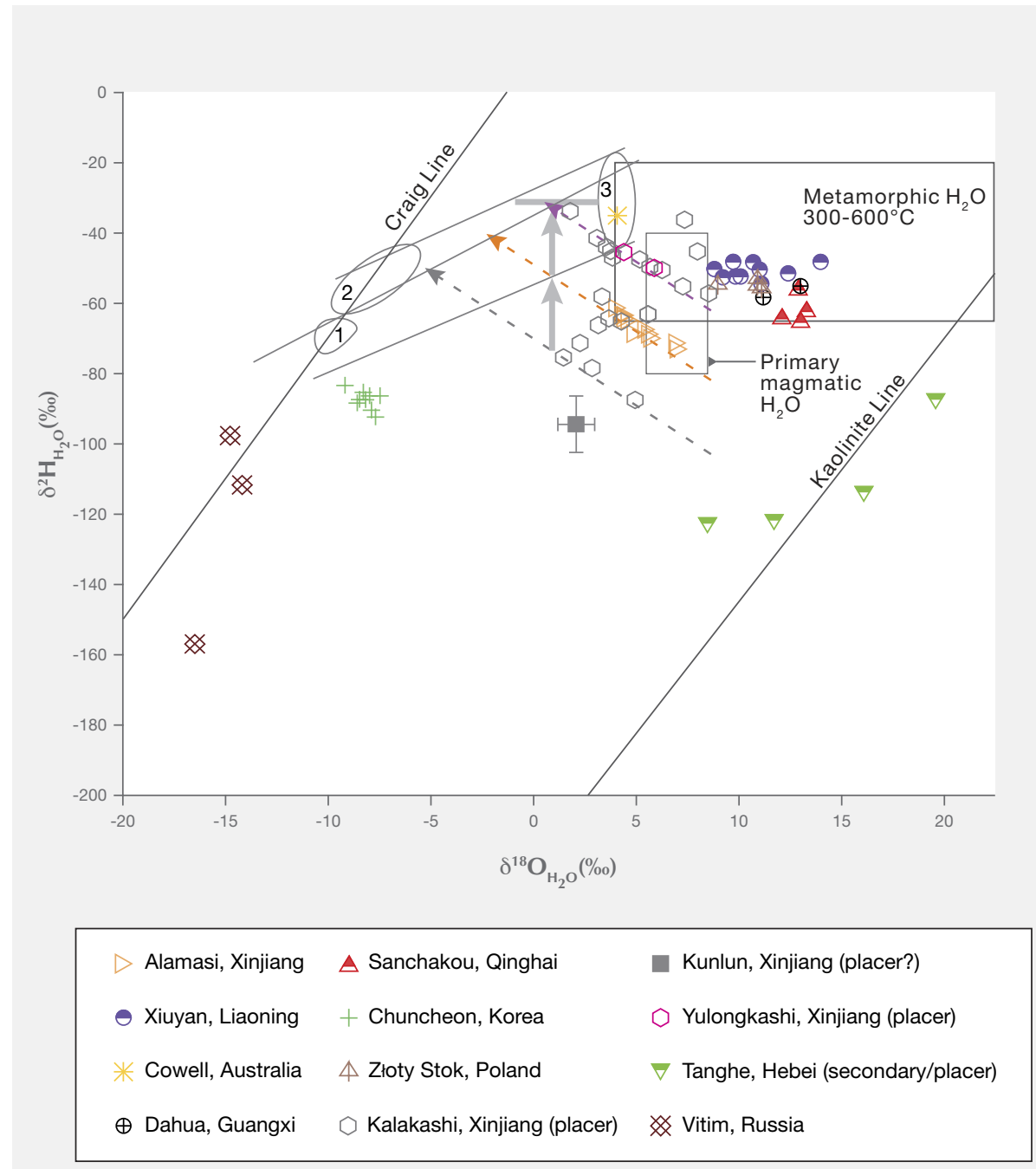

Figure 5. $\delta^{2} H_{H 2 O}$ and ${ }^{18} \mathrm{O}_{\mathrm{H} 2 \mathrm{O}}$ data of dolomiterelated nephrite-forming fluids at $350^{\circ} \mathrm{C}$. Nephrites from Alamasi, Yulongkashi, and Kalakashi show a trend marked by a set of arrows from the bottom right to the top left, which can be explained as dualistic fluid sources. Compared with the primary nephrite from Alamasi, the hydrogen isotope of placer nephrite changes greatly (indicated by the vertical arrow) without distinct $\delta^{18} \mathrm{O}_{\mathrm{H} 2 \mathrm{O}}$ variations, which are caused by fluid-rock reaction possibly. The ellipses represent hydrogen and oxygen isotopes of water from (1) the Qiemo River basin (Wang et al., 2013), covering the A'erjinshan region; (2) the Hetian River basin and Keliya River basin, covering the Alamasi, Agejugai, and Hetian regions; and (3) a pond in the Taklimakan Desert hinterland (Li et al., 2006). 
TABLE 2. Hydrogen and oxygen isotope delta values of dolomite-related nephrites.

\begin{tabular}{|c|c|c|c|c|c|c|c|c|}
\hline No. & $\delta^{18} \mathrm{O}(\% \mathrm{o})$ & $\delta^{2} \mathrm{H}(\% \mathrm{o})$ & $\begin{array}{c}\delta^{18} \mathrm{O}_{\mathrm{H}_{2} \mathrm{O}} \\
\left(350^{\circ} \mathrm{C}\right)(\% \circ)\end{array}$ & $\begin{array}{c}\delta^{2} \mathrm{H}_{\mathrm{H}_{2} \mathrm{O}} \\
\left(350^{\circ} \mathrm{C}\right)(\% \mathrm{o})\end{array}$ & Locality & Description & Mass spectrometer & Reference \\
\hline 1 & 3.8 & -86.7 & 4.5 & -65 & \multirow{14}{*}{$\begin{array}{l}\text { Alamasi, Yutian County, } \\
\text { Hetian (Xinjiang, China) }\end{array}$} & White & \multirow{11}{*}{ MAT-252 } & \multirow{11}{*}{ Liu et al. (2011a) } \\
\hline 2 & 3.2 & -83 & 3.9 & -61.3 & & White & & \\
\hline 3 & 6.1 & -93.1 & 6.8 & -71.4 & & White-green & & \\
\hline 4 & 4.6 & -89 & 5.3 & -67.3 & & White-green & & \\
\hline 5 & 3.5 & -85.1 & 4.2 & -63.4 & & White-green & & \\
\hline 6 & 3.6 & -85.9 & 4.3 & -64.2 & & White-green & & \\
\hline 7 & 6.2 & -94.7 & 6.9 & -73 & & White-green & & \\
\hline 8 & 4.1 & -90.2 & 4.8 & -68.5 & & Green & & \\
\hline 9 & 3.6 & -85 & 4.3 & -63.3 & & Green & & \\
\hline 10 & 4.9 & -91.6 & 5.6 & -69.9 & & Green & & \\
\hline 11 & 4.8 & -90.4 & 5.5 & -68.7 & & Green & & \\
\hline 13 & 3.8 & & 4.5 & & & White & & \multirow{7}{*}{ Wan et al. (2002) } \\
\hline 14 & 3.7 & & 4.4 & & & White-green & & \\
\hline 15 & 3.6 & & 4.3 & & & Green & & \\
\hline 16 & 2.3 & & 3.0 & & \multirow{4}{*}{$\begin{array}{l}\text { Agejugai, Hetian County, } \\
\text { Hetian (Xinjiang, China) }\end{array}$} & Mutton-fat & & \\
\hline 17 & 5.8 & & 6.5 & & & White & & \\
\hline 18 & 5.6 & & 6.3 & & & White-green & & \\
\hline 19 & 6.5 & & 7.2 & & & Green $^{\mathrm{b}}$ & & \\
\hline 20 & 5.3 & & 6.0 & & $\begin{array}{l}\text { Yecheng County, Kashi } \\
\text { (Xinjiang, China) }\end{array}$ & Green & & Wan et al. (2002) \\
\hline 21 & 4.6 & & 5.3 & & $\begin{array}{l}\text { Datong, Tashiku'ergan County, } \\
\text { Kashi (Xinjiang, China) }\end{array}$ & Green & & Wan et al. (2002) \\
\hline 23 & 3.4 & & 4.1 & & $\begin{array}{l}\text { Qiemo County, Bayinguoleng } \\
\text { (Xinjiang, China) }\end{array}$ & White-green & & Wan et al. (2002) \\
\hline 24 & 3.9 & & 4.6 & & \multirow{13}{*}{$\begin{array}{l}\text { Tashisayi Qiemo County, } \\
\text { Bayinguoleng (Xinjiang, } \\
\text { China) }\end{array}$} & Light brown & \multirow{13}{*}{ MAT-252 } & \multirow{13}{*}{ Wu $(2016)^{c}$} \\
\hline 25 & 4.8 & & 5.5 & & & Brown & & \\
\hline 26 & 4.7 & & 5.4 & & & Brown & & \\
\hline 27 & 5.6 & & 6.3 & & & White-green & & \\
\hline 28 & 4.6 & & 5.3 & & & Green & & \\
\hline 29 & 3 & & 3.7 & & & Green & & \\
\hline 30 & 3.6 & & 4.3 & & & Green & & \\
\hline 31 & 3.7 & & 4.4 & & & & & \\
\hline 32 & 3.1 & & 3.8 & & & & & \\
\hline 33 & 3.9 & & 4.6 & & & Green & & \\
\hline 34 & 4 & & 4.7 & & & Light brown & & \\
\hline 35 & 4.6 & & 5.3 & & & & & \\
\hline 36 & 4.8 & & 5.5 & & & & & \\
\hline 37 & 5.2 & -71.8 & 5.9 & -50.1 & \multirow{2}{*}{$\begin{array}{l}\text { Yulongkashi, Hetian (Xinjiang, } \\
\text { China) }\end{array}$} & White, placer & \multirow{2}{*}{ MAT-252 } & \multirow{2}{*}{ Liu et al. (2011b) } \\
\hline 38 & 3.7 & -67.3 & 4.4 & -45.6 & & White, placer & & \\
\hline 39 & 5.6 & -72.4 & 6.3 & -50.7 & \multirow{4}{*}{$\begin{array}{l}\text { Kalakashi, Hetian (Xinjiang, } \\
\text { China) }\end{array}$} & White-green, placer & \multirow{4}{*}{ MAT-252 } & \multirow{4}{*}{ Liu et al. (2011b) } \\
\hline 40 & 1.1 & -55.7 & 1.8 & -34 & & White-green, placer & & \\
\hline 41 & 5 & -71.4 & 5.7 & -49.7 & & White-green, placer & & \\
\hline 42 & 2.9 & -65.7 & 3.6 & -44 & & White-green, placer & & \\
\hline
\end{tabular}




\begin{tabular}{|c|c|c|c|c|c|c|c|c|}
\hline No. & $\delta^{18} \mathrm{O}(\%)$ & $\delta^{2} \mathrm{H}(\%)$ & $\begin{array}{c}\delta^{18} \mathrm{O}_{\mathrm{H}_{2} \mathrm{O}} \\
\left(350^{\circ} \mathrm{C}\right)(\% \text { o })\end{array}$ & $\begin{array}{c}\delta^{2} \mathrm{H}_{\mathrm{H}_{2} \mathrm{O}} \\
\left(350^{\circ} \mathrm{C}\right)(\%)\end{array}$ & Locality & Description & Mass spectrometer & Reference \\
\hline 43 & 3.2 & -68.7 & 3.9 & -47 & \multirow{17}{*}{$\begin{array}{l}\text { Kalakashi, Hetian (Xinjiang, } \\
\text { China) }\end{array}$} & Black, placer & \multirow{4}{*}{ MAT-252 } & \multirow{4}{*}{ Liu et al. (2011b) } \\
\hline 44 & 2.4 & -63.3 & 3.1 & -41.6 & & Black, placer & & \\
\hline 45 & 4.5 & -69.3 & 5.2 & -47.6 & & Black, placer & & \\
\hline 46 & 3.1 & -67.1 & 3.8 & -45.4 & & Black, placer & & \\
\hline 47 & 0.8 & -97 & 1.5 & -75.3 & & Green, placer & \multirow{13}{*}{ MAT-252 } & \multirow{13}{*}{ Liu et al. $(2016)^{d}$} \\
\hline 48 & 7.3 & -67 & 8.0 & -45.3 & & Black, placer & & \\
\hline 49 & 2.7 & -80 & 3.4 & -58.3 & & Black, placer & & \\
\hline 50 & 6.6 & -77 & 7.3 & -55.3 & & Black, placer & & \\
\hline 51 & 3.6 & -87 & 4.3 & -65.3 & & Green, placer & & \\
\hline 52 & 6.7 & -58 & 7.4 & -36.3 & & Black, placer & & \\
\hline 53 & 3 & -86 & 3.7 & -64.3 & & Black, placer & & \\
\hline 54 & 4.9 & -85 & 5.6 & -63.3 & & Green, placer & & \\
\hline 55 & 2.2 & -100 & 2.9 & -78.3 & & Black, placer & & \\
\hline 56 & 7.9 & -79 & 8.6 & -57.3 & & Black, placer & & \\
\hline 57 & 2.5 & -88 & 3.2 & -66.3 & & Green, placer & & \\
\hline 58 & 4.3 & -109 & 5.0 & -87.3 & & Green, placer & & \\
\hline 59 & 1.6 & -93 & 2.3 & -71.3 & & Green, placer & & \\
\hline 60 & 0.5 to 2.3 & -108 to -124 & 1.24 to 3.04 & -86.3 to -102.3 & Kunlun (Xinjiang, China) & $\begin{array}{l}\text { Primary or placer } \\
\text { unknown }\end{array}$ & & Yui and Kwon (2002) \\
\hline 61 & 12.3 & -76.9 & 13.0 & -55.2 & \multirow{2}{*}{ Dahua (Guangxi, China) } & & & \multirow{2}{*}{ Xu and Wang (2016) } \\
\hline 62 & 10.5 & -79.8 & 11.2 & -58.1 & & & & \\
\hline 63 & -8.7 & -108 & -8.0 & -86.3 & \multirow{9}{*}{ Chuncheon (South Korea) } & & & \multirow{9}{*}{ Yui and Kwon (2002) } \\
\hline 64 & -8.4 & -114 & -7.7 & -92.3 & & & & \\
\hline 65 & -9.9 & -105 & -9.2 & -83.3 & & & & \\
\hline 66 & -9 & -107 & -8.3 & -85.3 & & & & \\
\hline 67 & -8.2 & -108 & -7.5 & -86.3 & & & & \\
\hline 68 & -8.6 & -112 & -7.9 & -90.3 & & & & \\
\hline 69 & -8.9 & -109 & -8.2 & -87.3 & & & & \\
\hline 70 & -9.3 & -110 & -8.6 & -88.3 & & & & \\
\hline 71 & -9.2 & -109 & -8.5 & -87.3 & & & & \\
\hline 72 & 3.4 & -57 & 4.1 & -35.3 & $\begin{array}{l}\text { Cowell, South Australia } \\
\text { (Australia) }\end{array}$ & & & Yui and Kwon (2002) \\
\hline 73 & -15.52 & -119.3 & -14.8 & -97.6 & \multirow{9}{*}{ Vitim area, Buryatia (Russia) } & & \multirow{9}{*}{ MAT-253 } & \multirow{9}{*}{ Burtseva et al. (2015) } \\
\hline 74 & -16.8 & & -16.1 & & & & & \\
\hline 75 & -17.24 & -178.5 & -16.5 & -156.8 & & & & \\
\hline 76 & -15.51 & & -14.8 & & & & & \\
\hline 77 & -14.95 & & -14.2 & & & & & \\
\hline 78 & -14.93 & -133.2 & -14.2 & -111.5 & & & & \\
\hline 79 & -15.1 & & -14.4 & & & & & \\
\hline 80 & -14.58 & & -13.8 & & & & & \\
\hline 81 & -18.63 & & -17.9 & & & & & \\
\hline 82 & -17.33 & & -16.6 & & & $\begin{array}{l}\text { Semi-nephrite with } \\
\text { prismatic coarse- } \\
\text { grained tremolite }\end{array}$ & \multirow{3}{*}{ MAT-253 } & \multirow{3}{*}{ Burtseva et al. (2015) } \\
\hline 83 & -20.02 & & -19.3 & & Vitim area, Buryatia (Russia) & $\begin{array}{l}\text { Semi-nephrite with } \\
\text { prismatic coarse- } \\
\text { grained tremolite }\end{array}$ & & \\
\hline 84 & -17.24 & & -16.5 & & & $\begin{array}{l}\text { Semi-nephrite with } \\
\text { prismatic coarse- } \\
\text { grained tremolite }\end{array}$ & & \\
\hline
\end{tabular}


TABLE 2 (continued). Hydrogen and oxygen isotope delta values of dolomite-related nephrites.

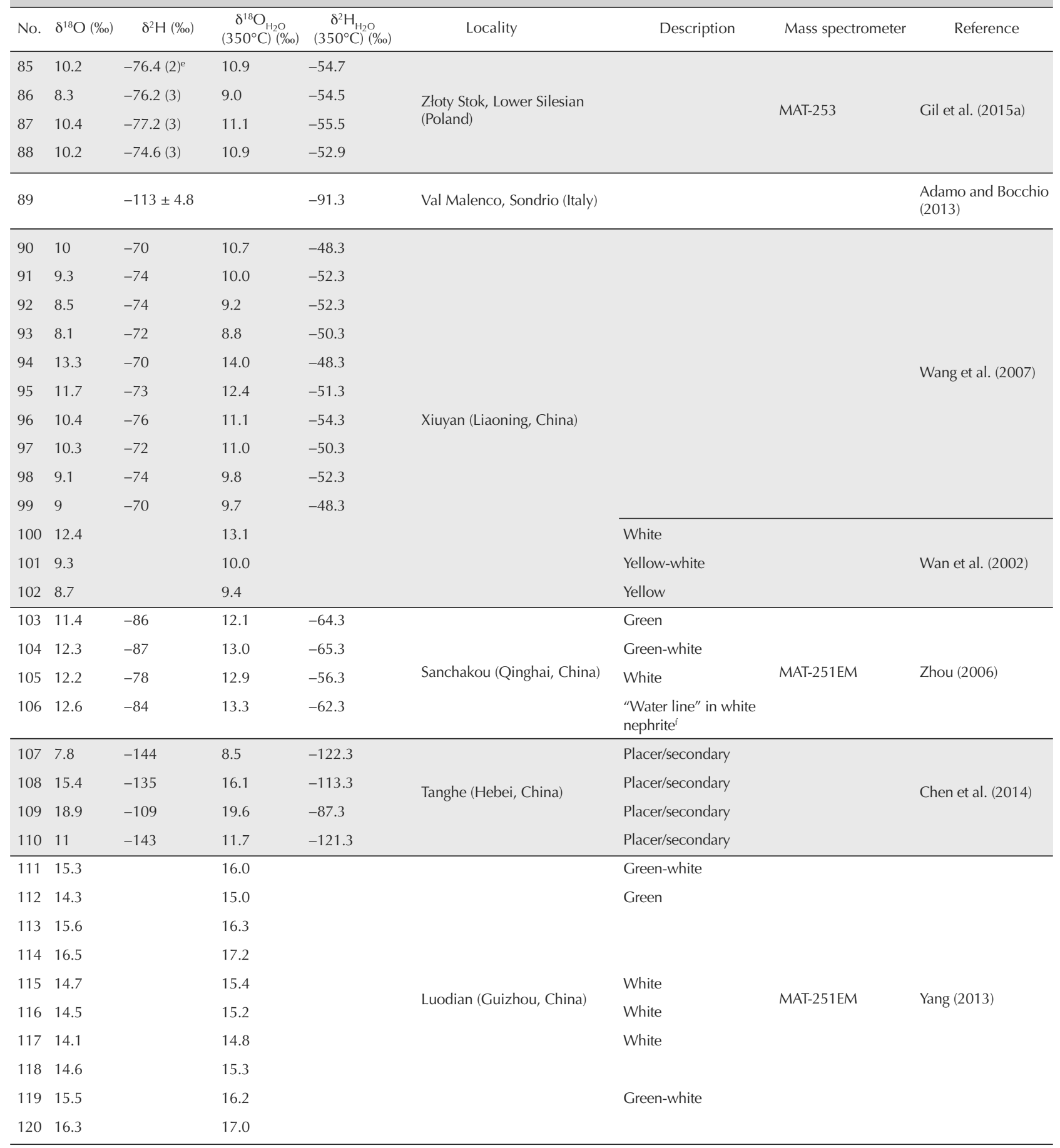

${ }^{a}$ The deposits in Hetian and Kashi are counted in the West Kunlun region, while those in Bayinguoleng are counted in the A'erjinshan rengion.

${ }^{b}$ The sample is marked as "Bi yu" in Chinese in the original reference, which mostly equates with serpentine-related nephrite. However, we tend to believe the original authors meant a nephrite with dark green color.

'Authors Kong Gao, Ting Fang, and Yuanyuan Wang once participated in the research project sponsoring the thesis. Therefore, we can supplement the content of the original literature, which is not detailed enough.

${ }^{d}$ Only those tremolite contents higher than 99 wt. \% are chosen from Liu et al. (2016). However, it is not ruled out that individual samples may be serpentine-related since their Fe contents can be high.

'The figure in parentheses is the number of samples tested. The number before the parentheses is the average value.

${ }^{f} A$ "water line" refers to the band in nephrite that is more transparent than the matrix. It is composed of prismatic coarse-grained tremolite crystals parallel to each other. 


\section{NEPHRITE-FORMING FLUIDS MODIFIED BY METAMORPHISM OR METASOMATISM}

The hydrogen and oxygen isotopes of nephrites from Xiuyan (Duan and Wang, 2002; Wan et al., 2002; Wang et al., 2007) and Złoty Stok (Gil et al., 2015a) overlap with each other to some extent (figure 4). Their calculated fluid isotopes plot in the regional metamorphic water field (figure 5), which is in accordance with their geological environment. The Xiuyan nephrite occurs not far from the famed serpentine jade deposit formed from metamorphic hydrothermal fluids (Wu et al., 2014). Silicon isotope studies support the interpretation that the formation of the Xiuyan nephrite was related to metamorphic fluids (Duan and Wang, 2002; Wu et al., 2014). At Złoty Stok, some geological bodies related to serpentine occur not far from the dolomite-related nephrite deposit (Gil et al., 2015a,b).

Like the nephrite-forming fluids of Xiuyan and Złoty Stok, those of Dahua and Sanchakou plot in the metamorphic water field (figure 5). The $\delta^{18} \mathrm{O}$ values of the Dahua, Sanchakou, and Luodian nephrites are higher than others (with the exception of Tanghe), and these deposits are related to basic igneous rocks of diabase or gabbro (Zhou et al., 2006; Yang et al., 2012; Li et al., 2014; Zhang et al., 2015; $\mathrm{Xu}$ and Wang, 2016), which is distinct from other dolomite-related nephrites. The presence of siliceous components in the wall rocks is another common feature for these three deposits. The wall rock for Dahua nephrite is a suite of interbedded layers of calcirudite, calcarenite, and micrite mixed with laminar siliceous rocks and paramoudra (Xu and Wang, 2016). Yang et al. (2013) discussed the relationship between nephrite formation and siliceous veins in the Sanchakou deposit. The country rocks around the Luodian nephrite are siliceous clayey micrites and cherty limestones (Yang et al., 2012; Li et al., 2014). These silicalites compensate for the Si shortage during the formation of nephrite from basic rocks. For Luodian nephrite, this is supported by the $\delta^{18} \mathrm{O}$ equilibrium between quartz and nephrite. The $\delta^{18} \mathrm{O}_{\mathrm{Qz}}$ value of the quartz from the deposit is $22.4 \%$ (Yang, 2013). Thus, the calculated $\delta^{18} \mathrm{O}_{\operatorname{Tr}}$ value for tremolite by the quartz-tremolite fractionation equation $10^{3} \ln \alpha_{\mathrm{Qz}-\mathrm{Tr}}=$ $2.25 \times 10^{6} / \mathrm{T}^{2}+0.46$ (Zheng, 1995 ) at $350^{\circ} \mathrm{C}$ equals $16.15 \%$, which is in the range of its nephrite $\delta^{18} \mathrm{O}$ value $=14.1 \%$ - $16.5 \%$ (Yang, 2013). The speculation of compensation is also supported by the $\mathrm{Si}$ isotope accordance between the nephrite and the siliceous veins, paramoudra, and silicalites $\left(\delta^{30} \mathrm{Si}=1.1 \% 0-1.7 \%\right.$; Yang, 2013). These values, in combination with field observations, indicate that the hydrothermal fluid forming Luodian nephrite derived from either diabase intrusion (Yang et al., 2012; Zhang et al., 2015) or seawater circulation driven by diabase intrusion (Li et al., 2014). A comparable process occurred at Sanchakou: The water in the sediments convected with magmatic hydrothermal fluids (Zhou, 2006), or the acidic magmatic hydrothermal fluids that extracted Mg from gabbro (Yang et al., 2013) reacted with wall rocks and formed nephrite. Obviously, the hydrothermal fluids that formed these nephrites were no longer the original magmatic hydrothermal fluids, but rather the fluids that had been modified by metasomatism.

\section{XINJIANG PLACER NEPHRITE ISOTOPES AND FLUID-ROCK REACTION}

The Xinjiang placer nephrites, which are mainly dug out from paleo river beds flowing through the Takelamagan Desert, differ from the primary ones by their wide ranges of hydrogen and oxygen isotope ratios, especially $\delta^{2} \mathrm{H}$ (figure 4). There are four factors potentially influencing this difference:

- Impurities: Impurities may induce a conspicuously high $\delta^{2} \mathrm{H}$ value (Liu et al., 2016), as well as a wide range of variation.

- Compositional effect: Most of the placer nephrite tested featured high Fe (Liu et al., 2011b, 2016), which can result in a compositional effect on hydrogen isotope fractionations in a tremolite- $\mathrm{H}_{2} \mathrm{O}$ system (Vennemann and O'Neil, 1996).

- Complicated derivations: Since several primary deposits occur in the upper reaches of the Yulongkashi and Kalakashi Rivers, the placer nephrite might come from different primary deposits, even including serpentine-related nephrite (Liu et al., 2016).

- Fluid-rock reaction: The $\delta^{2} \mathrm{H}-\delta^{18} \mathrm{O}$ trends of some of the Xinjiang placer nephrites are similar to those of the Alamasi nephrite (figure 4). The $\delta^{18} \mathrm{O}$ value, which is mainly controlled by the nephrite itself (Yui et al., 1990), has remained nearly constant after nephrite formation due to its high closure temperature of $424^{\circ} \mathrm{C}$ (Brady, 1995).

The closure temperature can be understood as the lowest temperature of isotope diffusion or loss. That is, the $\delta^{18} \mathrm{O}$ value of the placer nephrite is almost equal to that of the primary nephrites. The $\delta^{2} \mathrm{H}$ value 
of the placer nephrite, however, can be enhanced by the reaction between meteoric water (desert water that has been fractionated by evaporation; figure 5) and rock (nephrite).

The hydrogen in hydrous minerals diffuses rapidly and shows a closure temperature, below which it will no longer diffuse and change its composition, in cooling metamorphic rocks far below the formation temperature of the mineral assemblages (Graham, 1981). The closure temperature $\left(T_{c}\right)$ for hydrogen isotope volume diffusion can be expressed as (Dodson, 1973):

$$
\mathrm{T}_{\mathrm{c}}=\mathrm{R} /\left[\mathrm{E} \ln \left(\frac{\mathrm{A} \tau \mathrm{D}_{0}}{\mathrm{a}^{2}}\right)\right]
$$

where the time constant is

$$
\tau=-\mathrm{RT}^{2} /\left(\frac{\mathrm{E} d T}{d t}\right)
$$

in which the activation energy for tremolite $E=71.5$ kJ/mol (Graham et al., 1984; Farver, 2010); the gas constant $R=8.314 \mathrm{~J} / \mathrm{mol} / \mathrm{K}$; the anisotropic factor for cylinder case $A=27$ (Dodson, 1973); the pre-exponential factor in the Arrhenius relationship $D_{0}=1.21 \times$ $10^{-8} \mathrm{~m}^{2} / \mathrm{s}$, calculated from figure 5 of Graham et al. (1984). Thus, the closure temperature can be as low as $61^{\circ} \mathrm{C}$ (calculated by grain radius $a=0.5 \mu \mathrm{m}$, cooling rate $d T / d t=-10^{\circ} \mathrm{C} / \mathrm{d}$ ) to $123^{\circ} \mathrm{C}$ (calculated by $a=1$ $\mu \mathrm{m}, d T / d t=-50^{\circ} \mathrm{C} / \mathrm{d}$ ). Since the radius of nephrite tremolite can be smaller, the calculated closure temperature will decrease. Furthermore, an experiment showed that tremolite can dissolve at a $\mathrm{pH}$ of 6.9 at a low temperature of $37^{\circ} \mathrm{C}$ (Diedrich et al., 2014). Grapes and Sun (2010) suggested that higher porosity created by actinolite dissolution results in an exponential increase in weathering. Tremolite fibers, with lower iron concentration than actinolite, have high chemical reactivity as well (Pacella et al., 2015). Thus, the hydrogen isotope ratio can re-equilibrate at low temperature between the placer nephrite and meteoric water, enhancing the $\delta^{2} \mathrm{H}$ value of the former.

\section{CONCLUSIONS}

On the basis of formation environment and formation process, hydrogen and oxygen isotope ratios of nephrites from around the world can be analyzed. These isotope ratios, even for oxygen alone, appear to be discrimination criteria for the geographic origin determination of dolomite-related nephrites, especially those from Vitim (Russia), Chuncheon (South Korea) and the Xinjiang Uyghur Autonomous Region and Qinghai Province of China. However, the nephrite $\delta^{18} \mathrm{O}$ values from Xiuyan, Dahua, and Złoty Stok overlap. The isotopic ratio differences are mainly derived from the ore-forming fluids. The isotopes of dolomite-related nephrites from Russia, South Korea, Xinjiang, and Qinghai Province increase in sequence, and the ore-forming fluids vary in the order of meteoric water $\rightarrow$ mixture of magmatic water and meteoric water $\rightarrow$ mixed water that experienced metamorphism to some extent or is even dominated by metamorphic fluid. Furthermore, the hydrogen isotope of the placer nephrite from the Hetian region of Xinjiang could have been modified by meteoric water when it was buried in paleo river beds flowing through the desert.

Based on this limited data set, we show that isotope ratio analysis is a new gem origin identification tool for gemologists studying nephrite (similar to what other researchers have shown for emerald and corundum). However, we point out with caution that more data is needed to optimize our findings.
ABOUT THE AUTHORS

Dr. Gao is a research group leader of the National Gems \& Jewellery Technology Administrative Center (NGTC) and director of the application R\&D department at the Shenzhen Research Institute, NGTC. Ms. Fang is a postgraduate at the University of Science and Technology Beijing. Dr. Lu is chief scientist of NGTC. Mr. Lan is principal instrument researcher of NGTC, director of Shenzhen Research Institute, and vice director of Shenzhen Lab, NGTC. Mr. Zhang is a research group leader of NGTC and vice director of Shenzhen Lab, NGTC. Ms. Wang is an analytical technician, and Mr. Chang is an engineer, at the China Hetian Jade Product Quality Supervision Testing Center (Xinjiang).

\section{ACKNOWLEDGMENTS}

The authors wish to express their gratitude for reviewers Dr. Yunbin Guan at Caltech, Dr. Andy Shen, Dr. George Rossman, and Dr. Ahmadjan Abduriyim for their thorough reviews of this manuscript and helpful comments and criticism. We thank technical editors Jennifer Stone-Sundberg and Tao Z. Hsu for their elaborate work handling the manuscript. We also appreciate Professor Guanghai Shi for his constructive suggestions. 


\section{REFERENCES}

Abduriyim A., Kitawaki H. (2006) Applications of laser ablationinductively coupled plasma-mass spectrometry (LA-ICP-MS) to gemology. Ge G, Vol. 42, No. 2, pp. 98-118, http://dx.doi.org/10.5741/GEMS.42.2.98

Adamo I., Bocchio R. (2013) Nephrite jade from Val Malenco, Italy: Review and update. $G \uplus G$, Vol. 49, No. 2, pp. 2-10, http://dx.doi.org/10.5741/GEMS.49.2.98

Brady J.B. (1995) Diffusion Data for Silicate Minerals, Glasses, and Liquids. American Geophysical Union, Washington, DC.

Burtseva M.V., Ripp G.S., Posokhov V.F., Murzintseva A.E. (2015) Nephrites of East Siberia: Geochemical features and problems of genesis. Russian Geology and Geophysics, Vol. 56, No. 3, pp. 402-410, http://dx.doi.org/10.1016/j.rgg.2015.02.003

Chen C., Yu X.J., Wang S.Q. (2014) Study on gemmological characteristics and ore genesis of nephrite from Tanghe, Hebei Province. Journal of Gems and Gemmology, Vol. 16, No. 3, pp. 1-11 (in Chinese with English abstract), http://dx.doi.org/10.15964/j.cnki.027jgg.2014.03.001

Craig H. (1961) Isotopic variations in meteoric waters. Science, Vol. 133, No. 3465, pp. 1702-1703, http://dx.doi.org/10.1126/science.133.3465.1702

Diedrich T., Schott J., Oelkers E.H. (2014) An experimental study of tremolite dissolution rates as a function of $\mathrm{pH}$ and temperature: Implications for tremolite toxicity and its use in carbon storage. Mineralogical Magazine, Vol. 78, No. 6, pp. 1449-1464, http://dx.doi.org/10.1180/minmag.2014.078.6.12

Dodson M.H. (1973) Closure temperature in cooling geochronological and petrological systems. Contributions to Mineralogy and Petrology, Vol. 40, No. 3, pp. 259-274, http://dx.doi.org/10.1007/BF00373790

Duan T.Y., Wang S.Q. (2002) Study on stable isotopes of Xiuyan nephrite (tremolite). Acta Petrologica et Mineralogica, Vol. 21, No. S1, pp. 115-119 (in Chinese with English abstract).

Farver J.R. (2010) Oxygen and hydrogen diffusion in minerals. Reviews in Mineralogy and Geochemistry, Vol. 72, No. 1, pp. 447-507, http://dx.doi.org/10.2138/rmg.2010.72.10

Gil G., Barnes J.D., Boschi C., Gunia P., Raczyński P., Szakmány G., Bendő Z., Péterdi B. (2015a) Nephrite from Złoty Stok (Sudetes, SW Poland): Petrological, geochemical, and isotopic evidence for a dolomite-related origin. The Canadian Mineralogist, Vol. 53, No. 3, pp. 533-556, http://dx.doi.org/10.3749/canmin.1500018

Gil G., Barnes J.D., Boschi C., Gunia P., Szakmány G., Bendö Z., Raczyński P., Péterdi B. (2015b) Origin of serpentinite-related nephrite from Jordanów and adjacent areas (SW Poland) and its comparison with selected nephrite occurrences. Geological Quarterly, Vol. 59, No. 3, pp. 457-472, http://dx.doi.org/10.7306/gq.1228

Giuliani G., France-Lanord C., Coget P., Schwarz D., Cheilletz A., Branquet Y., Giard D., Martin-Izard A., Alexandrov P., Piat D.H. (1998) Oxygen isotope systematics of emerald: Relevance for its origin and geological significance. Mineralium Deposita, Vol. 33, No. 5, pp. 513-519, http://dx.doi.org/10.1007/s001260050166

Giuliani G., Chaussidon M., Schubnel H., Piat D.H., RollionBard C., France-Lanord C., Giard D., de Narvaez D., Rondeau B. (2000) Oxygen isotopes and emerald trade routes since antiquity. Science, Vol. 287, No. 5453, pp. 631-633, http://dx.doi.org/10.1126/science.287.5453.631

Giuliani G., Fallick A.E., Garnier V., France-Lanord C., Ohnenstetter D., Schwarz D. (2005) Oxygen isotope composition as a tracer for the origins of rubies and sapphires. Geology, Vol. 33, No. 4, pp. 249-252, http://dx.doi.org/10.1130/G21261.1

Giuliani G., Fallick A., Rakotondrazafy M., Ohnenstetter D., Andriamamonjy A., Ralantoarison T., Rakotosamizanany S., Tseheno M.R., Offant Y., Garnier V., Dunaigre C., Schwarz D., Mercier A., Ratrimo V., Ralison B. (2007) Oxygen isotope systematics of gem corundum deposits in Madagascar: Relevance for their geological origin. Mineralium Deposita, Vol. 42, No.
3, pp. 251-270, http://dx.doi.org/10.1007/s00126-006-0105-3

Graham C.M. (1981) Experimental hydrogen isotope studies III: Diffusion of hydrogen in hydrous minerals, and stable isotope exchange in metamorphic rocks. Contributions to Mineralogy and Petrology, Vol. 76, No. 2, pp. 216-228, http://dx.doi.org/10.1007/BF00371961

Graham C.M., Harmon R.S., Sheppard S.M.F. (1984) Experimental hydrogen isotope studies: Hydrogen isotope exchange between amphibole and water. American Mineralogist, Vol. 69, No. 12, pp. 128-138.

Grapes R.H., Yun S.T. (2010) Geochemistry of a New Zealand nephrite weathering rind. New Zealand Journal of Geology and Geophysics, Vol. 53, No. 4, pp. 413-426.

Harlow G.E., Sorensen S.S. (2005) Jade (nephrite and jadeitite) and serpentinite: Metasomatic connections. International Geology Review, Vol. 47, No. 2, pp. 113-146, http://dx.doi.org/10.2747/0020-6814.47.2.113

Li K.X., Jiang T.L., Xing L.C., Zhou M.Z., Luo T.Y. (2014) A preliminary study on mineralogy and ore deposits genetical model of luodian nephrite jade, Luodian, Guizhou Province, China. Acta Mineralogica Sinica, Vol. 34, No. 2, pp. 223-233 (in Chinese with English abstract), http://dx.doi.org/10.16461/j.cnki.10004734.2014.02.013

Li W.P., Hao A.B., Zheng Y.J., Liu B., Yu D.S. (2006) Regional environmental isotopic features of groundwater and their hydrogeological explanation in the Tarim Basin. Earth Science Frontiers, Vol. 13, No. 1, pp. 191-198 (in Chinese with English abstract), http://dx.doi.org/10.3321/j.issn:1005-2321.2006.01.025

Link K. (2015) Age determination of zircon inclusions in faceted sapphires. Journal of Gemmology, Vol. 34, No. 8, pp. 692-700.

Liu Y., Deng J., Shi G.H., Lu T.J., He H.Y., Ng Y.N., Shen C.H., Yang L.Q., Wang Q.F. (2010) Chemical zone of nephrite in Alamas, Xinjiang, China. Resource Geology, Vol. 60, No. 3, pp 249-259, http://dx.doi.org/10.1111/j.1751-3928.2010.00135.x

Liu Y., Deng J., Shi G.H., Yui T.F., Zhang G.B., Abuduwayiti M. Yang L.Q., Sun X. (2011a) Geochemistry and petrology of nephrite from Alamas, Xinjiang, NW China. Journal of Asian Earth Sciences, Vol. 42, No. 3, pp. 440-451, http://dx.doi.org/10.1016/j.jseaes.2011.05.012

Liu Y., Deng J., Shi G.H., Sun X., Yang L.Q. (2011b) Geochemistry and petrogenesis of placer nephrite from Hetian, Xinjiang, Northwest China. Ore Geology Reviews, Vol. 41, No. 1, pp. 122-132, http://dx.doi.org/10.1016/j.oregeorev.2011.07.004

Liu Y., Zhang R.Q., Abuduwayiti M., Wang C., Zhang S.P., Shen C.H., Zhang Z.Y., He M.Y., Zhang Y., Yang X.D. (2016) SHRIMP $\mathrm{U}-\mathrm{Pb}$ zircon ages, mineral compositions and geochemistry of placer nephrite in the Yurungkash and Karakash River deposits, West Kunlun, Xinjiang, northwest China: Implication for a magnesium skarn. Ore Geology Reviews, Vol. 72, pp. 699-727, http://dx.doi.org/10.1016/j.oregeorev.2015.08.023

Luo Z.M., Yang M.X., Shen A.H. (2015) Origin determination of dolomite-related white nephrite through iterative-binary linear discriminant analysis. Ge G, Vol. 51, No. 3, pp. 300-311, http://dx.doi.org/10.5741/GEMS.51.3.300

Pacella A., Fantauzzi M., Turci F., Cremisini C., Montereali M.R., Nardi E., Atzei D., Rossi A., Andreozzi G.B. (2015) Surface alteration mechanism and topochemistry of iron in tremolite asbestos: A step toward understanding the potential hazard of amphibole asbestos. Chemical Geology, Vol. 405, pp. 28-38, http://dx.doi.org/10.1016/j.chemgeo.2015.03.028

Tang Y.L., Chen B.Z., Jiang R.H. (1994) Chinese Hetian Nephrite, Xinjiang. Xinjiang People's Publishing House, Xinjiang (in Chinese)

Vennemann T.W., O'Neil J.R. (1996) Hydrogen isotope exchange reactions between hydrous minerals and molecular hydrogen: I. A new approach for the determination of hydrogen isotope fractionation at moderate temperatures. Geochimica et Cos- 
mochimica Acta, Vol. 60, No. 13, pp. 2437-2451, https://dx.doi.org/10.1016/0016-7037(96)00103-2

Wan D.F., Wang H.P., Zou T.R. (2002) Silicon and oxygen isotopic compositions of Hetian jade, Manasi green jade and Xiuyan old jade (tremolite). Acta Petrologica et Mineralogica, Vol. 21, No. S1, pp. 110-114 (in Chinese with English abstract).

Wang H.A.O., Krzemnicki M.S., Chalain J. (2016) Simultaneous high sensitivity trace-element and isotopic analysis of gemstones using laser ablation inductively coupled plasma timeof-flight mass spectrometry. Journal of Gemmology, Vol. 35, No. 3, pp. 212-223.

Wang H.A.O., Cartier L.E., Baumgartner L.P., et al (2018) A preliminary SIMS study using carbon isotopes to separate natural from synthetic diamonds. Journal of Gemmology, Vol. 36, No. 1 , pp. 38-43.

Wang K., Graham I., Martin L., Voudouris P., Giuliani G., Lay A., Harris S., Fallick A. (2019) Fingerprinting Paranesti rubies through oxygen isotopes. Minerals, Vol. 9, No. 2, pp. 91, http://dx.doi.org/10.3390/min9020091

Wang S.Q., Zhao C.H., Yu G., Yuan X.M., Duan T.Y. (2007) Xiuyan Jades in China. Science Press, Beijing (in Chinese).

Wang W.X., Wang R.J., Li W.P., Yin X.L., Liu C.L. (2013) Analysis of stable isotopes and hydrochemistry of rivers in Tarim Basin. Hydrogeology et) Engineering Geology, Vol. 40, No. 4, pp. 29-35 (in Chinese with English abstract), http://dx.doi.org/10.16030/j.cnki.issn.1000-3665.2013.04.020

Wang W.Y., D'Haenens-Johansson U., Smit K., Breeding C.M., Stern R. (2014) Carbon isotope analysis of CVD synthetic gem diamonds. In 2014 GSA Annual Meeting in Vancouver, British Columbia.

Wu L.J. (2016) Study on gemological and mineralogical characteristics and genesis of nephrite in Tiantai, Qiemo, Xinjiang. Master's thesis. China University of Geosciences, Beijing.

Wu Z.Y., Wang S.Q., Ling X.X. (2014) Characteristics and origin of nephrite from Sangpiyu, Xiuyan County, Lioaning Province. Acta Petrologica et Mineralogica, Vol. 33, No. S2, pp. 15-24 (in Chinese with English abstract).

Xu L.G., Wang S.Q. (2016) Gemological characteristics and genesis of Dahua nephrite. Acta Petrologica et Mineralogica, Vol. 35, No. S1, pp. 1-11 (in Chinese with English abstract).

Yang F.X., Abduriyim A. (1994) Honten jade and its marketing. Journal of China Gemstone, Vol. 1, pp. 81-84.

Yang L. (2013) Study on petro-mineral features and genetic mechanism of Luodian jade, Guizhou Province. Ph.D. thesis. Chengdu University of Technology, Chengdu.

Yang L., Lin J.H., Wang L., Tan J., Wang B. (2012) Petrochemical characteristics and genesic significance of Luodian jade from
Guizhou. Journal of Mineralogy and Petrology, Vol. 32, No. 2, pp. 12-19 (in Chinese with English abstract), http://dx.doi.org/10.3969/j.issn.1001-6872.2012.02.003

Yang T.X., Yang M.X., Liu H.L., Wu Y., Li J. (2013) New understanding for Sanchahe nephrite deposit in East Kunlun. Journal of Guilin University of Technology, Vol. 33, No. 2, pp. 239-245 (in Chinese with English abstract), http://dx.doi.org/10.3969/j.issn.1674-9057.2013.02.007

Yui T.F., Kwon S.T. (2002) Origin of a dolomite-related jade deposit at Chuncheon, Korea. Economic Geology, Vol. 97, No. 3, pp. 593-601, http://dx.doi.org/10.2113/97.3.593

Yui T.F., Yeh H.W., Lee C.W. (1988) Stable isotope studies of nephrite deposits from Fengtien, Taiwan. Geochimica et Cosmochimica Acta, Vol. 52, No. 3, pp. 593-602, https://dx.doi.org/10.1016/0016-7037/88/90321-3

- (1990) A stable isotope study of serpentinization in the Fengtien ophiolite, Taiwan. Geochimica et Cosmochimica Acta, Vol. 54, No. 5, pp. 1417-1426, https://dx.doi.org/10.1016/0016-7037/90|90165-H

Zhang Y.D., Yang R.D., Gao J.B., Chen I., Liu Y.N., Zhou Z.R. (2015) Geochemical characteristics of nephrite from Luodian County, Guizhou Province, China. Acta Mineralogica Sinica, Vol. 35, No. 1, pp. 56-64 (in Chinese with English abstract), http://dx.doi.org/10.16461/i.cnki.1000-4734.2015.01.009

Zheng Y.F. (1993) Calculation of oxygen isotope fractionation in hydroxyl-bearing silicates. Earth and Planetary Science Letters, Vol. 120, No. 3-4, pp. 247-263, http://dx.doi.org/10.1016/0012 821X(93) $90243-3$

(1995) Oxygen isotope fractionation in amphiboles. Science Geologica Sinica, Vol. 30, No. 1, pp. 1-11 (in Chinese with English abstract).

Zheng Y.F., Chen J.F. (2000) Stable Isotope Geochemistry. Science Press, Beijing (in Chinese).

Zhong Y.P., Qiu Z.L., Li L.F., Gu X.Z., Luo H., Chen Y., Jiang Q.Y. (2013) REE composition of nephrite jades from major mines in China and their significance for indicating origin. Journal of the Chinese Society of Rare Earths, Vol. 31, No. 6, pp. 738-748 (in Chinese with English abstract).

Zhou Z.Y. (2006) Study on ore-forming tectonic setting and mechanism of Sanchakou nephrite (tremolite Jade), East Kunlun. Ph.D. thesis, Tongji University, Shanghai.

Zhou Z.Y., Liao Z.T., Ma T.T., Yuan Y. (2006) Study on the genetic mechanism and material source of Sanchakou nephrite deposit in East Kunlun. Contributions to Geology and Mineral Resources Research, Vol. 21, No. 3, pp. 195-198, 202 (in Chinese with English abstract), http://dx.doi.org/10.3969/j.issn.10011412.2006.03.010 